\title{
GROWTH AND MINERAL NUTRITION OF Ipomoea quamoclit
}

\author{
Crescimento e Nutrição Mineral de Ipomoea quamoclit
}

CARVALHO, L.B. ${ }^{2}$, BIANCO, S. ${ }^{3}$ e PITELLI, R.A. ${ }^{3}$

\begin{abstract}
A greenhouse experiment was carried out from November 2006 to April 2007 at FCAV/UNESP, Brazil, aiming to study the dry mass production and the accumulation and distribution of macronutrients in Ipomoea quamoclit, an important weed for annual and perennial crops in Brazil. The plants were grown in seven liter pots with sand substrate, daily irrigated with Hoagland \& Arnon nutrient solution. The experimental design was completely randomized with four replicates. The treatments corresponded to evaluation times at 14 day intervals, beginning 21 days after emergence (DAE). In each evaluation, the plants of four pots were analyzed in function of dry mass production and macronutrient content. I. quamoclit had a small dry mass and macronutrient accumulation at the beginning of the experimental stage, increasing after $77 \mathrm{DAE}$ and reaching the maximum theoretical value at 146, 143, 140,149,142, 153, and $124 \mathrm{DAE}$, for dry mass, $\mathrm{N}, \mathrm{P}, \mathrm{K}, \mathrm{Ca}, \mathrm{Mg}$, and $\mathrm{S}$, respectively. $\mathrm{K}$ and $\mathrm{N}$ were the macronutrients most accumulated by $I$. quamoclit plants.
\end{abstract}

Keywords: weeds, morningglory, dry mass, macronutrients.

\begin{abstract}
RESUMO - Um experimento em casa de vegetação foi conduzido entre novembro de 2006 e abril de 2007, na FCAV/UNESP, Brasil, objetivando estudar a produção de massa seca, a distribuição e o acúmulo de macronutrientes por Ipomoea quamoclit, uma importante planta infestante de culturas anuais e perenes no Brasil. As plantas foram cultivadas em vasos de $7 \mathrm{~L}$ com substrato de areia, que foram irrigados diariamente com solução nutritiva de Hoagland \& Arnon. O delineamento experimental foi inteiramente casualizado, com quatro repetições. Os tratamentos corresponderam às épocas de avaliação, em intervalos de 14 dias, iniciando-se 21 dias após a emergência (DAE). Em cada avaliação, as plantas de quatro vasos foram analisadas quanto à produção de massa seca e ao conteúdo de macronutrientes. I. quamoclit apresentou pequeno acúmulo de massa seca e de macronutrientes no início da fase experimental. Esses acúmulos intensificaram-se após 77 DAE, atingindo o máximo valorteórico aos 146, 143, 140, 149, 142, 153 e 124 DAE, para massa seca, $N, P, K, C a, M g$ e $S$, respectivamente. $K$ e $N$ foram os macronutrientes acumulados em maior quantidade por plantas de I. quamoclit.
\end{abstract}

Palavras-chave: plantas daninhas, corda-de-viola, massa seca, macronutrientes.

\section{INTRODUCTION}

Ipomoea quamoclit $\mathrm{L}$. is an indigenous to Tropical America, widely distributed in other tropical regions around the world (Kissmann \& Groth, 1999). In Brazil, I. quamoclit is a frequent weed in most summer annual crops, especially in the Southeast and Northeast regions, providing operation problems in mechanical harvesting due to its climbing growth habit (Lorenzi, 2000).

In general, weeds have a specific characteristic that allows their eco-physiological adjustment in different environments, known as phenotypic plasticity; at each environment,

1 Recebido para publicação em 12.3.2008 e na forma revisada em 5.6.2009.

2 Bolsista CNPq, Pós-graduando em Produção Vegetal da FCAV/UNESP, Via de Acesso Professor Paulo Donato Castellane, s/n, 14884-900 Jaboticabal-SP, <agrolbcarvalho@gmail.com>; ${ }^{3}$ Docentes da FCAV/UNESP. 
weed populations can suffer evolving genetic modifications that can be extended to subsequent generations (Pitelli \& Pavani, 2004). For these reasons, weed populations can show different responses to distinct methods of management. Thus, basic studies on the biology of weeds are essential to understand the behavior of weeds growing under different environmental conditions (Bianco et al., 2004a,b), as a support to weed management.

Considering the importance of I. quamoclit as weed, basic studies are necessary concerning the biology of this species, regarding some aspects such as reproduction, growth, development and mineral nutrition, as we1l as management systems. These studies are important to obtain substantial information to help manage this weed.

Information on the nutritional requirements of weeds is important to weed science; since nutrient competition is one of the main ecological factors that affect negatively crop productivity (Andreasen et al., 2006; Olykan et al., 2008). Due to this fact, important works have been already conducted for Senna obtusifolia (Erasmo et al., 2000), Urena lobata (Souza Filho et al., 2000), Hyptis suaveolens (Gravena et al., 2002), Cardiospermum halicacabum (Brighenti et al., 2003), Richardia brasiliensis competing with Glycine max (Pedrinho Júnior et al., 2004), Quercus petraea, Fagus sylvatica, Acer pseudoplatanus (Kazda et al. 2004), Brachiaria decumbens (Bianco et al., 2005), Euphorbia heterophylla competing with G. $\max$ (Bianco et al. (2007), Brachiaria plantaginea competing with Zea mays (Carvalho et al., 2007) and Ipomoea nil (Duarte et al., 2008).

No information is available in the literature on growth and mineral nutrition of I. quamoclit. However, efforts must be done to study the biology of this important weed which greatly affects sugar cane, soybean and maize harvesting in Brazil.

The objective of this research was to study the dry mass production and macronutrients distribution and accumulation in I. quamoclit plants, growing under standard nutrient conditions.

\section{MATERIALS AND METHODS}

A greenhouse trial was carried out at the Faculty of Agrarian and Veterinarian Sciences (FCAV), São Paulo State University (UNESP), Jaboticabal-SP, Brazil. The experiment was conducted from November 2006 to April 2007, using seven liter plastic pots and river sand as substrate.

Twenty seeds of I. quamoclit were sown in November 2006. After two pairs of leaves were obtained, only four I. quamoclit plants per plot were maintained until the end of the experimental stage.

The pots were irrigated three times a day with nutrient solution of Hoagland \& Arnon (1950). AT 35 days after emergence (DAE), the irrigation was performed at a concentration of $25 \%$ of this solution; after $35 \mathrm{DAE}$ until the end of the experimental stage, at a concentration of $50 \%$. These concentrations were obtained mixing the original solution with de-ionized water in proportion of $1: 3(25 \%)$ and $1: 1(50 \%)$.

The experimental design was completely randomized with four replicates. Treatments were determined by proper evaluation times at $21,35,49,63,77,91,105,119,133,147$ and $161 \mathrm{DAE}$. At each time, plants from the four pots were analyzed, considering each pot as one replicate.

For the evaluations, I. quamoclit plants were collected and partitioned into roots, stems, leaves and reproductive structures (flowers and fruits). These materials were washed according to procedure described by Sarruge \& Haag (1974) and dried at $60-70^{\circ} \mathrm{C}$ in a forced air convection oven during 96 hours.

Dried materials were weighted to determine the dry mass accumulation, sequentially powdered using a Wiley mill grinder with 20-mesh steel screen and stored in glass pots with silicon lid.

Ground samples were submitted to different extraction methods for nutrient rate determination in roots, stems, leaves, and reproductive structures. Nitrogen $(\mathrm{N})$ and phosphorus $(\mathrm{P})$ rates were attained according to the methodologies described by Sarruge $\&$ 
Haag (1974). Potassium (K), calcium (Ca) and magnesium $(\mathrm{Mg})$ rates were determined according to the methodologies described by Jorgensen (1977), while sulfur (S) rate was reached according to methodology described by Vitti (1989).

Macronutrient accumulation in the roots, stems, leaves and reproductive structures was calculated by multiplying the nutrient rate in each structure and the correspondent dry mass accumulation. Total accumulation of each macronutrient was calculated by adding the accumulation of the nutrient in the roots, stems, leaves and reproductive structures. The total rate for each macronutrient was achieved in function of the relation between total nutrient accumulation and total dry mass accumulation.

Accumulation of dry mass and macronutrients were submitted to regression analysis in function of the theoretical exponential model $y=\exp \left(a+b x+c x^{2}\right)$ : where $y$ indicates dry mass or macronutrient accumulation and $x$ represents days after emergence. So, points of maximum theoretical dry mass (PMtADM) and macronutrient (PMtAM) accumulation were calculated by the first derivative of the adjusted equation.

\section{RESULTS AND DISCUSSION}

Dry mass accumulation for I. quamoclit plants was slow at the beginning of the experimental stage (Figure 1A), but reached a theoretical value of $6.46 \mathrm{~g}$ per plant at the PMtADM (146 DAE). After this period, there was

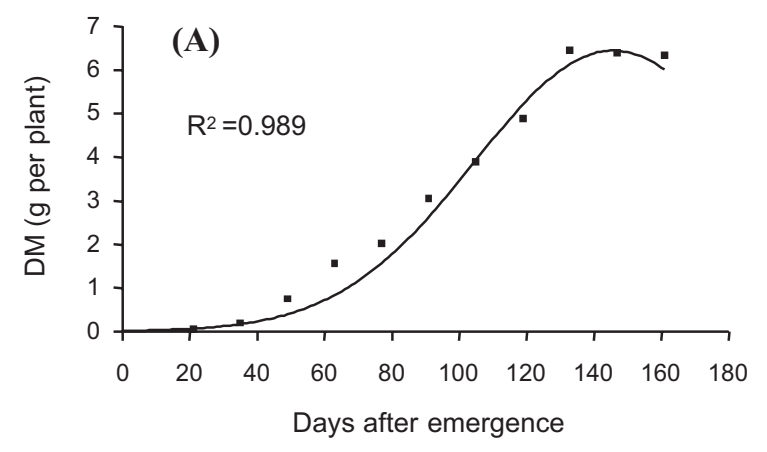

$y=\exp \left(-4.5004+0.087377 x-0.0003 x^{2}\right)$ a reduction of total dry mass accumulation due to plant senescence. Duarte et al. (2008) observed that $I$. nil accumulated more dry mass at 123 DAE; furthermore, I. quamoclit presented less dry mass accumulation than I. nil, growing under the same conditions.

It was ascertained considerable dry mass accumulation from 77 to 133 DAE (Figure 1A). During this period, high dry mass increase occurred mainly as a function of accumulation in the stems (Figure 1B). I. quamoclit is a climbing plant with long stems (Lorenzi, 2000), and its life cycle is more prolonged than the agricultural cycle of annual crops, providing substantial harvest problems and indirect yield losses when the weed is not controlled.

Dividing the experimental stage into three parts, the percentage of accumulated dry mass in the leaves was higher than in the other structures in the first part, while stem percentage was greater than in other structures in the third part (Figure 2). This trend was also verified for $I$. nil (Duarte et al., 2008). This behavior may have occurred due to the growth habit of these species.

The percentage of accumulated dry mass in the roots increased from 21 to 49 DAE, decreasing afterwards (Figure 2). This slight increase may have allowed the plant to be able to fix itself on the substrate, increasing the contact with the nutrients, thereby leading to their quick uptake (Carvalho et al., 2007).

The percentage of dry mass accumulation in the stems increased substantially after 49 DAE, decreasing mainly in the leaves

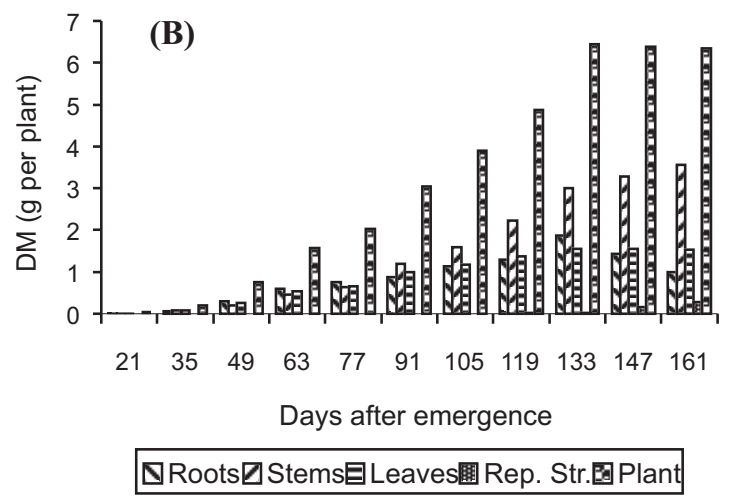

Figure 1 - Regression of the mean data (A) and distribution (B) of dry mass accumulation in Ipomoea quamoclit plants grown under standard nutrient conditions. FCAV/UNESP, Brazil, 2007. 


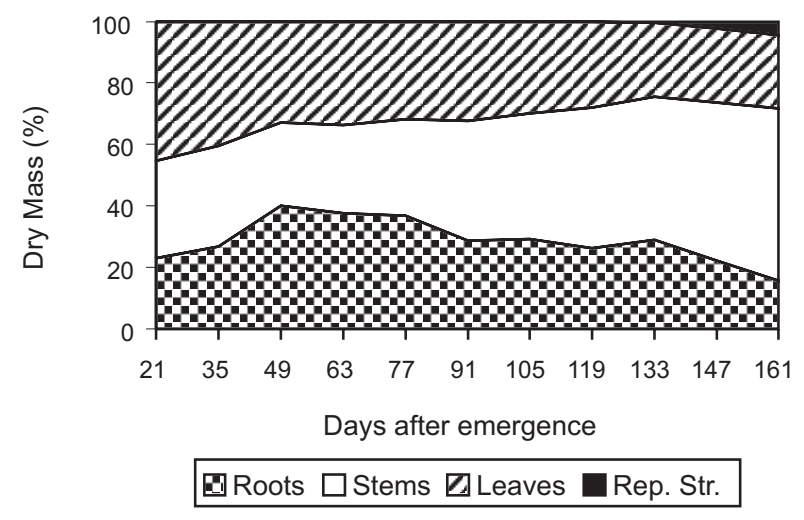

Figure 2 - Dry mass distribution (\%) in Ipomoea quamoclit plants grown under standard nutrient conditions. FCAV/UNESP, Brazil, 2007.

(Figure 2). It provided greater percentage of dry mass accumulation in the stems than other structures from 91 to $161 \mathrm{DAE}$. This can be explained by the climbing growth habit of I. quamoclit, which has stems that grow quickly giving support to the plant to obtain sunlight needed for photosynthesis.

Flowering of $I$. quamoclit occurred between 119 and 133 DAE. The highest dry mass accumulation in the reproductive structures, $0.28 \mathrm{~g}$ per plant, occurred at $161 \mathrm{DAE}$ (Figure 1B). The percentage of accumulated dry mass in the reproductive structures was small, but the highest value was $4.35 \%$ at $161 \mathrm{DAE}$ (Figure 2).

It is important to point out that there was intense decrease in the percentage of accumulated dry mass in the leaves after flowering (Figure 2) likely due to the change of the main site of nutrient absorption from the leaves to the reproductive structures. This fact had also been observed in studies with other weeds, according to reports by Bianco et al. (2004b) on Desmodium tortuosum, Bianco et al. (2004a) on Rottboellia exaltata, Pedrinho Júnior et al. (2004) on R. brasiliensis, Bianco et al. (2007) on E. heterophylla, Carvalho et al. (2007) on B. plantaginea and Duarte et al. (2008) on I. nil.

The sequence of macronutrients with the highest rates in I. quamoclit plants was $\mathrm{K}, \mathrm{N}$, $\mathrm{Ca}, \mathrm{Mg}, \mathrm{P}$ and $\mathrm{S}$, respectively (Table 1). Macronutrients rates oscillated throughout the experimental stage. The highest rate of $\mathrm{N}$ was observed at $63 \mathrm{DAE}$, whereas the $\mathrm{P}, \mathrm{K}, \mathrm{Ca}$,
$\mathrm{Mg}$ and $\mathrm{S}$ highest rates were verified at 77 DAE. When studying mineral nutrition in broadleaved weeds, Bianco et al. (2004a), Bianco et al. (2004b), Pedrinho Júnior et al. (2004) and Bianco et al. (2007) observed that K and $\mathrm{N}$ were the macronutrients presenting the highest rates in plants such as $R$. exaltata, $D$. tortuosum, R. brasiliensis and E. heterophylla, respectively. Duarte et al. (2008) also reported the highest rates of $\mathrm{K}$ and $\mathrm{N}$ in $\mathrm{I}$. nil.

The accumulation of macronutrients in I. quamoclit plants was small at the beginning of the experimental stage (Figure 3), increasing after the first part of the total stage, reaching the PMtAM at $143 \mathrm{DAE}$ (167.62 $\mathrm{mg}$ of $\mathrm{N}$ per plant), $140 \mathrm{DAE}$ (15.41 mg of $\mathrm{P}$ per plant), $149 \mathrm{DAE}$ (149.45 mg of K per plant), $142 \mathrm{DAE}$ (74.48 mg of Ca per plant), $153 \mathrm{DAE}$ (26.88 mg of Mg per plant) and $145 \mathrm{DAE}$ (14.80 $\mathrm{mg}$ of S per plant).

A large accumulation of $\mathrm{N}$ from 77 to 119 DAE (Figure 3A) was verified. There was a real accumulation of $142.65 \mathrm{mg}$ of $\mathrm{N}$ per plant at 119 DAE. Nevertheless, a great accumulation of $\mathrm{P}, \mathrm{K}, \mathrm{Ca}, \mathrm{Mg}$ and $\mathrm{S}$ from 63 to $133 \mathrm{DAE}$ (Figures 3B, 3C, 3D, 3E, and 3F) was verified. There were real accumulations of $15.61 \mathrm{mg}$ of $\mathrm{P}$ per plant, $136.56 \mathrm{mg}$ of $\mathrm{K}$ per plant, $68.09 \mathrm{mg}$ of Ca per plant, $23.53 \mathrm{mg}$ of $\mathrm{Mg}$ per plant and $13.68 \mathrm{mg}$ of $\mathrm{S}$ per plant at 133 DAE.

Comparing the results of this research with that obtained on I. nil, it can be shown

Table 1 - Rates of macronutrients $\left(\mathrm{g} \mathrm{kg}^{-1}\right)$ in Ipomoea quamoclit plants grown under standard nutrient conditions. FCAV/UNESP, Brazil, 2007

\begin{tabular}{|r|c|c|c|c|c|c|}
\hline DAE & $\mathrm{N}$ & $\mathrm{P}$ & $\mathrm{K}$ & $\mathrm{Ca}$ & $\mathrm{Mg}$ & $\mathrm{S}$ \\
\hline 21 & 27.32 & 2.47 & 30.00 & 11.55 & 3.73 & 1.84 \\
\hline 35 & 24.03 & 2.04 & 33.78 & 12.72 & 3.66 & 1.67 \\
\hline 49 & 22.20 & 1.69 & 22.53 & 11.25 & 3.02 & 1.35 \\
\hline 63 & 29.75 & 2.65 & 26.77 & 13.70 & 3.36 & 1.64 \\
\hline 77 & 26.60 & 3.47 & 46.02 & 14.25 & 4.47 & 2.33 \\
\hline 91 & 25.62 & 2.86 & 25.24 & 12.24 & 3.94 & 2.09 \\
\hline 105 & 25.70 & 2.73 & 27.58 & 13.34 & 3.95 & 2.10 \\
\hline 119 & 26.43 & 2.66 & 21.58 & 12.28 & 3.94 & 2.43 \\
\hline 133 & 22.13 & 2.42 & 21.20 & 10.57 & 3.65 & 2.12 \\
\hline 147 & 23.60 & 2.11 & 21.54 & 10.04 & 3.29 & 1.99 \\
\hline 161 & 23.37 & 2.44 & 20.95 & 10.33 & 3.64 & 2.16 \\
\hline
\end{tabular}

DAE - Days after emergence. 


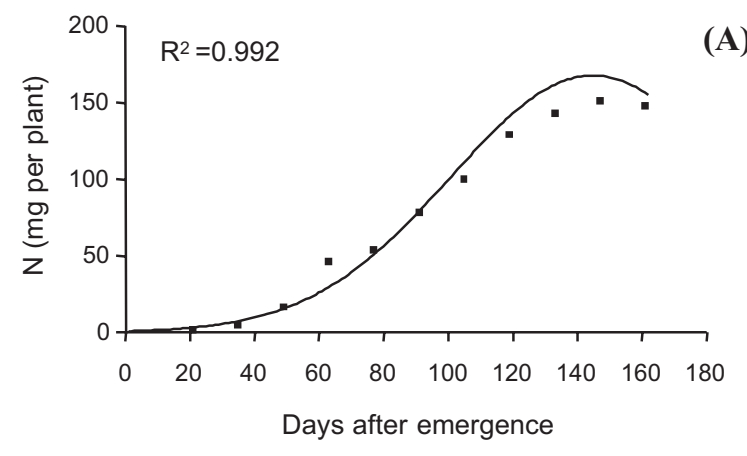

$y=\exp \left(-0.25324+0.074766 x-0.00026 x^{2}\right)$

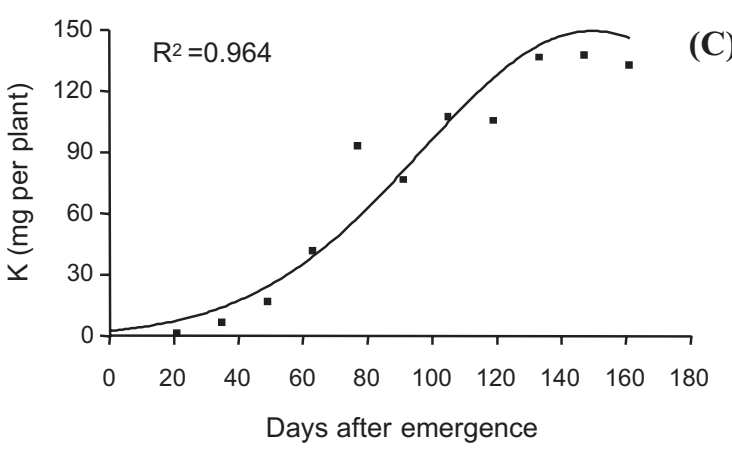

$y=\exp \left(0.988148+0.053792 x-0.00018 x^{2}\right)$

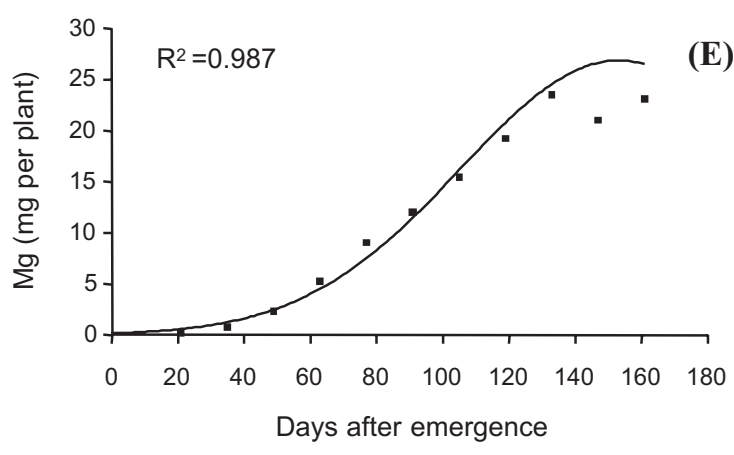

$y=\exp \left(-1.8661+0.067368 x-0.00022 x^{2}\right)$

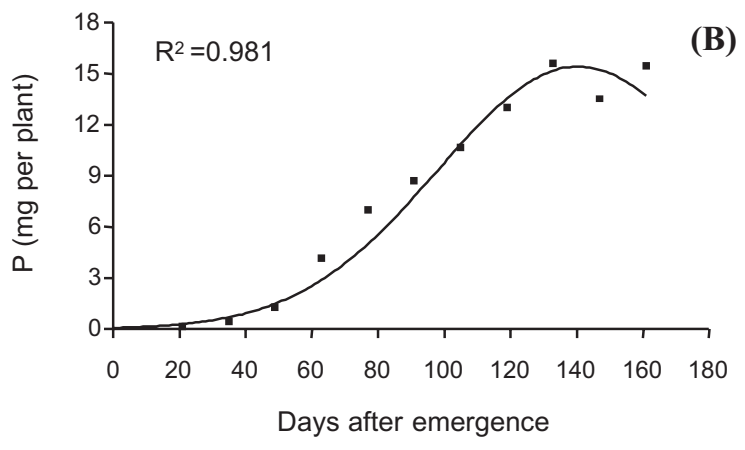

$y=\exp \left(-2.7902+0.078666 x-0.00028 x^{2}\right)$

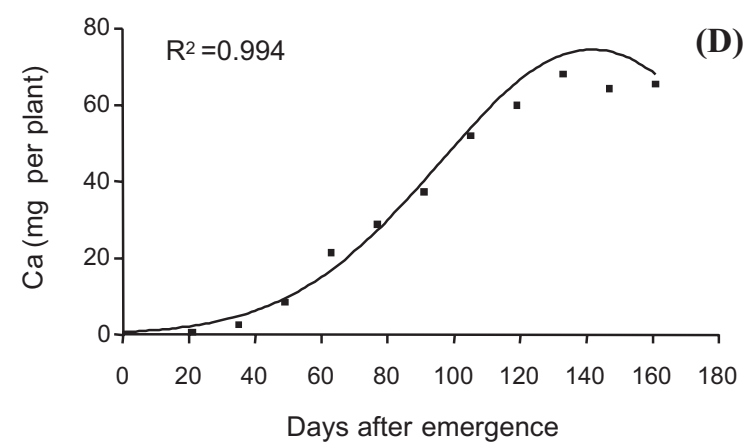

$y=\exp \left(-0.50513+0.067993 x-0.00024 x^{2}\right)$

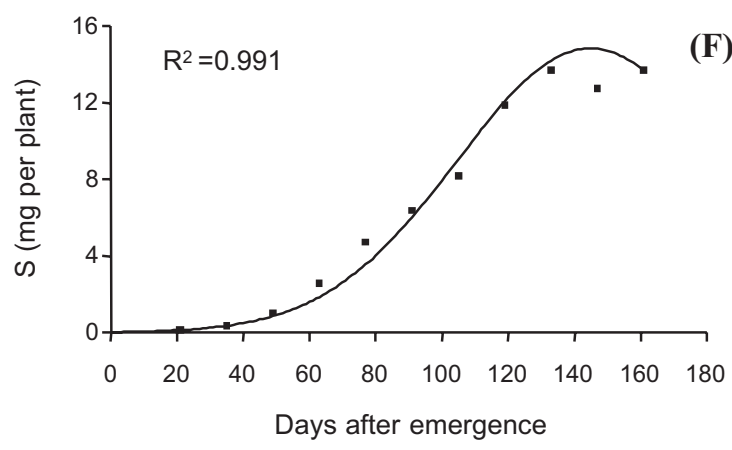

$y=\exp \left(-3.8152+0.089855 x-0.00031 x^{2}\right)$

Figure 3 - Regression of the mean data of accumulation of nitrogen (A), phosphorus (B), potassium (C), calcium (D), magnesium (E), and sulfur (F) in Ipomoea quamoclit plants grown under standard nutrient conditions. FCAV/UNESP,Brazil, 2007.

that, on the PMtAM, I. quamoclit accumulated less $\mathrm{N}, \mathrm{P}, \mathrm{K}, \mathrm{Ca}, \mathrm{Mg}$, and $\mathrm{S}$ than I. nil (Duarte et al., 2008). Therefore, I. quamoclit was less demanding for macronutrients than I. nil.

The macronutrients that accumulated the most in I. quamoclit plants were those displaying the highest rates. $\mathrm{N}$ accumulated more than $\mathrm{K}$. The uptake sequence was $\mathrm{N}>\mathrm{K}$ $>\mathrm{Ca}>\mathrm{Mg}>\mathrm{P}>\mathrm{S}$. Bianco et al. (2004a,b), Pedrinho Júnior et al. (2004) and Bianco et al. (2007) observed that $\mathrm{N}$ and $\mathrm{K}$ accumulated the most in the broadleaved weeds already studied. $\mathrm{N}$ and $\mathrm{K}$ are also known as the most demanded 
nutrients for most crops of economic interest (Epstein \& Bloom, 2005). Thus, competition of I. quamoclit plants for macronutrients is an important biotic factor negatively affecting crop growth, development and productivity.

Bianco et al. (2004a,b) and Bianco et al. (2007) reported that the period for the greatest competition for nutrients among weeds and most annual crops in Brazil is around 77 DAE; as a result of uptake intensification, which was also observed in this study. During this period, just one $I$. quamoclit plant accumulated $2.02 \mathrm{~g}$ of dry mass, $53.69 \mathrm{mg}$ of $\mathrm{N}, 7.00 \mathrm{mg}$ of $\mathrm{P}$, $92.92 \mathrm{mg}$ of $\mathrm{K}, 28.77 \mathrm{mg}$ of $\mathrm{Ca}, 9.03 \mathrm{mg}$ of $\mathrm{Mg}$ and $4.71 \mathrm{mg}$ of $\mathrm{S}$.

Comparing these results with those obtained by Duarte et al. (2008), it can be stated that I. quamoclit is less competitive for macronutrients than $I$. nil at $77 \mathrm{DAE}$, growing under standard nutrient conditions.

Therefore: (i) leaves and stems are the main structures accumulating dry mass in the first and second half of the I. quamoclit life cycle, respectively; (ii) $\mathrm{N}$ and $\mathrm{K}$ are the macronutrients most accumulated by I. quamoclit plants; and (iii) theoretical period of maximum dry mass and macronutrient accumulation by I. quamoclit was between 140 and 149 DAE.

\section{LITERATURE CITED}

ANDREASEN, C.; LITZ, A. S.; STREIBIG, J. C. Growth response of six weed species and spring barley (Hordeum vulgare) to increasing levels of nitrogen and phosphorus. Weed Technol., v. 46, n. 6, p. 503-512, 2006.

BIANCO, S.; BARBOSA JÚNIOR, A. F.; PITELLI, R. A. Crescimento e nutrição mineral de capim-camalote. Planta Daninha, v. 22, n. 3, p. 375-380, 2004a.

BIANCO, S.; PITELLI, R. A.; BELLINGIERI, P. A. Crescimento e nutrição mineral de Desmodium tortuosum (Sw.) DC. Cult. Agron., v. 13, n. 2, p. 78-88, 2004 b.

BIANCO, S.; TONHÃO, M. A. R.; PITELLI, R. A. Crescimento e nutrição mineral de capim-braquiária. Planta Daninha, v. 23, n. 3, p. 423-428, 2005.

BIANCO, S.; PITELLI, R. A.; CARVALHO, L. B. Estudo comparativo do acúmulo de massa seca e macronutrientes por plantas de Glycine max (L.) Merr. e Euphorbia heterophylla L. Ensaios e Ci., v. 11, n. 2, p. 61-72, 2007.

BRIGHENTI, A. M.; VOLL, E.; GAZZIERO, D. L. P. Biologia e manejo do Cardiospermum halicacabum. Planta Daninha, v. 21, n. 2, p. 229-237, 2003.

Planta Daninha, Viçosa-MG, v. 27, n. 2, p. 283-288, 2009
CARVALHO, L. B. et al. Estudo comparativo do acúmulo de massa seca e macronutrientes por plantas de milho var. BR-106 e Brachiaria plantaginea. Planta Daninha, v. 25, n. 2, p. 293-301, 2007.

DUARTE, D. J. et al. Crescimento e nutrição mineral de Ipomoea nil. Planta Daninha, v. 26, n. 3, p.577-583, 2008

EPSTEIN, E.; BLOOM, A. J. Mineral nutrition of plants: principles and perspectives. 2.ed. Massachussets: Sinauer, 2005. $380 \mathrm{p}$.

ERASMO, E. A. L. et al. Efeito de níveis crescentes de calagem no crescimento e estado nutricional de fedegoso. Planta Daninha, v. 18, n. 2, p. 253-263, 2000.

GRAVENA, R. et al. Análise do crescimento de Hyptis suaveolens. Planta Daninha, v. 20, n. 2, p. 189-196, 2002.

HOAGLAND, D. R.; ARNON, D. J. The water culture method of growing plants without soil. Berkeley: University of California, 1950. 31 p. (Circular, 347).

JORGENSEN, S. S. Metodologia utilizada para análises químicas de rotina: guia analítico. Piracicaba: CENA, 1977. $24 \mathrm{p}$.

KAZDA, M. et al. Importance of mineral nutrition for photosynthesis and growth of Quercus petraea, Fagus sylvatica and Acer pseudoplatanus planted under Norway spruce canopy. Plant Soil, v. 264, n. 1-2, p. 25-34, 2004.

KISSMANN, K. G; GROTH, D. Plantas infestantes e nocivas. TOMO II. 2.ed. São Paulo: BASF, 1999. 978 p.

LORENZI, H. Plantas daninhas do Brasil: terrestres, aquáticas, parasitas e tóxicas. 3.ed. Nova Odessa: Instituto Plantarum, 2000. 608 p.

OLYKAN, S. T. et al. Effect of boron fertiliser, weed control and genotype on foliar nutrients and tree growth of juvenile Pinus radiata at two contrasting sites in New Zealand. For. Ecol. Manage., v. 255, n. 3-4, p. 1196-1209, 2008.

PEDRINHO JÚNIOR, A. A. F.; BIANCO, S.; PITELLI, R. A Acúmulo de massa seca e macronutrientes por plantas de Glycine max e Richardia brasiliensis. Planta Daninha, v. 22, n. 1, p. 53-61, 2004.

PITELLI, R. A.; PAVANI, M. C. M. D. Feralidade e trangienese. In: BOREM, A. (Org.). Biotecnologia e meio ambiente. Viçosa: UFV, 2004. p. 263-278.

SARRUGE, J. R.; HAAG, H. P. Análises químicas em plantas. Piracicaba: ESALQ/USP, 1974. 56 p.

SOUZA FILHO, A. P. S.; VELOSO, C. A. C.; GAMA, J. R. N. Capacidade de absorção de nutrientes do capimmarandu (Brachiaria brizantha) e da planta daninha malva (Urena lobata) em função do pH. Planta Daninha, v. 18, n. 3, p. $443-450,2000$.

VITTI, G.C. Avaliação e interpretação do enxofre no solo e na planta. Jaboticabal: FUNEP, 1989. 37 p. 